\title{
The Effectiveness of Improving the Understanding of Indonesian Students Department of Indonesian Literature of Andalas University Through the Language Card Playing Method
}

\author{
Ria Febrina ${ }^{1, *}$ and M. Yusuf ${ }^{2}$ \\ ${ }^{1}$ Department of Indonesian Literature, Andalas University, Indonesia, 25163 \\ ${ }^{2}$ Department of Indonesian Literature, Andalas University, Indonesia, 25163 \\ *Corresponding author. Email: riafebrina003@ gmail.com ${ }^{1}$
}

\begin{abstract}
The Penyuntingan course is a course that practices the Bahasa skills of students in editing scientific texts according to Bahasa rules. However, the proficiency of students of the Indonesian Literature Department, Andalas University, has still not achieved these learning objectives. In the Penyuntingan I course, a language card game method was prepared so that the students could understand the editing rules stated in Law No. 50 of 2015 which is Pedoman Umum Ejaan Bahasa Indonesia (PUEBI) and Kamus Besar Bahasa Indonesia (KBBI). The students are formed into the small groups, then they are asked to make 154 language cards which are the application of 154 PUEBI materials. After that, one playing method is chosen, such as playing cards, uno card games, monopoly games, or snakes and ladders to play the language cards. The results showed that the language card playing method was effectively implemented as a learning method for Penyuntingan I courses. Through this method, the students could understand 154 Indonesian rules in Pedoman Umum Ejaan Bahasa Indonesia (PUEBI).
\end{abstract}

Keywords: Learning methods, Bahasa, language cards, penyuntingan, vocabulary

\section{INTRODUCTION}

The Penyuntingan I course (INA459-Sasindo) is a cluster elective course in fourth semester in the Indonesian Literature Department, Andalas University. In this course, the basic theory of editing is discussed from the nature, categories, patterns, conditions, and stages of editing. The material in the practical field includes how to edit various texts for various purposes, as well as language editing practices, both spelling, words, diction, phrases, sentences, paragraphs, and discourse.

Even though it has been studied by the students of the Indonesian Literature Department, Andalas University, Febrina and Wahyuni (2018: 58-59) stated that based on the results of the Bahasa test conducted in 2018, it was concluded that the Bahasa skills of Indonesian Literature Department students FIB Unand were on average at the madya rank with a score of 482-577 and the rank of semenjana with a score of 405-481. The rating can be seen as follows.

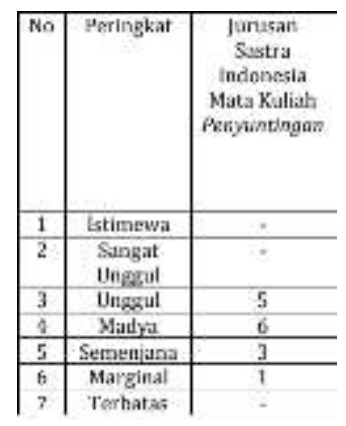

Table 1. List of Bahasa Test Scores for Indonesian Literature Department Students, Faculty of Cultural Sciences, Andalas University in 2018 (Febrina and Wahyuni, 2018: 58)

Based on the government Regulation no. 57 of 2014, the madya ranking is intended for high school level students because they already have adequate proficiency in communicating, both oral and written, but they are still experiencing professional problems. Meanwhile, the semenjana ranking is aimed at junior high school level students because they have sufficient proficiency in communicating in Bahasa but 
they experience difficulties in communicating for complex professional and social needs.

From table 1, it is shown that the scores achieved by Indonesian Literature Department students in the Penyuntingan II course are unggul (5 people), madya ( 6 people), semenjana ( 3 people), and marginal (1 person). Based on Government Regulation no. 57 of 2014, the marginal ranking is intended for elementary students because their skills are inadequate in communicating using Bahasa, both spoken and written.

The Penyuntingan II course is a course that practices the Bahasa skills of each student in editing scientific manuscripts in accordance with Bahasa rules. Based on the tests conducted, only $33 \%$ of the students were deemed fit to edit. There are $67 \%$ of the students cannot be trusted to become the editors. It shows that the Bahasa proficiency of the students of the Indonesian Literature Department, Faculty of Cultural Sciences, Andalas University is still very low. In fact, the students who take the Penyuntingan II course are the students who have completed at least six semesters of lectures. It means that these students can submit a research proposal for a bachelor's degree. Thus, the skills of the students of the Faculty of Cultural Sciences, Andalas University, especially the students of the Indonesian Literature Department need to be reviewed. With these scores, it is feared that the written thesis does not meet the correct Bahasa rules. As a Bahasa experts, they should have become a good and correct reflection or model of using Bahasa. Moreover, Bahasa is the official language of the country which is used in various formal and nonformal varieties.

Therefore, since the beginning of the Penyuntingan I course, it is necessary to make a certain efforts, such as preparing a representative learning method so that the students can understand the rules of editing listed in Law No. 50 of 2015 which is Pedoman Umum Ejaan Bahasa Indonesia (PUEBI) and Kamus Besar Bahasa Indonesia (KBBI). This is intended for the learning objectives of the Penyuntingan I course so it can be achieved, including (1) having sufficient knowledge of editing; (2) able to adequately edit various edited manuscripts with a pattern on universal and environmental rules; and (3) having a positive attitude towards the editing profession and the prospects for editing in Indonesia. So far, the Penyuntingan $I$ course has been implemented by using a combination of Teacher Centered Leaning (TCL) and Student Centered Leaning (SCL) methods. In the application of Teacher Centered Leaning (TCL), the students are given a list of textbook references that are used for one semester and the lecturers convey the lesson themes by using the lecture method. In the application of the Student Centered Leaning (SCL), the students are given editing exercises, then they are analyzed together. When measuring the students 'abilities through the mid-semester test (UTS) and the end-semester test (UAS), the students' abilities did not reach the expected targets. It can be seen in the scores obtained by the following students:

\begin{tabular}{|c|c|c|c|c|c|c|c|c|c|}
\hline $\begin{array}{l}\text { VALUE } \\
\text { DISTRI } \\
\text { BUTIO } \\
\mathbf{N}\end{array}$ & $\begin{array}{l}\mathrm{A} \\
\mathrm{A}\end{array}$ & A- & $\begin{array}{l}\text { B } \\
+\end{array}$ & $\begin{array}{l}\mathrm{b} \\
\mathrm{B}\end{array}$ & $\begin{array}{l}\text { B } \\
\text { B } \\
-\end{array}$ & $\begin{array}{l}\mathrm{C} \\
\mathrm{C} \\
+\end{array}$ & $\begin{array}{l}\mathrm{C} \\
\mathrm{C}\end{array}$ & $\begin{array}{l}\mathrm{D} \\
\mathrm{D}\end{array}$ & $\begin{array}{l}\mathrm{E} \\
\mathrm{E}\end{array}$ \\
\hline $\begin{array}{l}\text { NUMB } \\
\text { ER OF } \\
\text { STUDE } \\
\text { NTS }\end{array}$ & 6 & 15 & $\begin{array}{l}1 \\
2\end{array}$ & 4 & 1 & 0 & 0 & 0 & 2 \\
\hline PERCE & 1 & 37 & 3 & 1 & 2. & 1. & 1. & 0 & 5 \\
\hline NTAG & 5 & .5 & 0 & 0 & 5 & 5 & 5 & $\%$ & $\%$ \\
\hline $\mathbf{E}$ & $\%$ & $\%$ & $\%$ & $\%$ & $\%$ & $\%$ & $\%$ & & \\
\hline
\end{tabular}

Table 2. The Distribution of TheStudent Values in Penyuntingan I Course at Even Semester 2018/2019

Through this table, it can be seen that the students' scores in Penyuntingan $I$ have not been maximal. Even though it is quite good, the ability of the students after graduating from lectures does not meet the expected learning outcomes.

The use of the SCL method by doing the exercises in the class turned out to be unable to meet the learning outcomes that had been prepared for the Penyuntingan $I$ course. Therefore, it is necessary to design a new method to improve the students' memory regarding Bahasa rules. The new method designed for Penyuntingan I learning is the language card playing method. According to Vygotsky (in Mutiah, 2010: 103), playing has a direct role in the development of one's cognition. Playing is a way of thinking and a way of solving problems.

Dworetzky (in Ardy and Barnawi, 2012: 122$123)$ provides a limitation that there are at least five criteria in playing which are (1) intrinsic motivation, it means that playing activities are motivated from within a person, not due to demands or coercion; (2) positive influence, it means that playing activities are fun or joyful behavior; (3) not done casually, it means that playing is the main and more pretend activity; (4) method / goals, it is how to play takes precedence over the goal; and (5) flexibility, it means that flexibility is shown both in form and in relationships and applies in every situation.

With this playing method, it is hoped that the students of the Indonesian Literature Department, Andalas University can add to their PUEBI and KBBI knowledge in a fun way. Thus, the material does not burden their minds, but instead it provides good knowledge and stimulation when editing manuscripts, such as papers, theses, books, and creative works, such as poetry, short stories, and novels.

Meanwhile, the playing method used is the language card playing method. The media of word cards (flashcards) was introduced by Glenn Doman, a brain surgeon from Philadelphia. The word card media contains words or pictures grouped according to themes. According to the Badan Pengembangan dan Pembinaan Bahasa Republik Indonesia (2016), the cards are thick paper, rectangular in shape, while words are elements of spoken or written language which embody the unity of feelings and thoughts that can be used in language. 
Glen Doman's idea was created into the language cards. On the card, it is not only the words are written as knowledge, but also related to the letter writing, word writing, use of punctuation marks, and writing of absorption elements. By using the language card playing method, the students are expected to be able to understand 154 concepts regarding to the Pedoman Umum Ejaan Bahasa Indonesia (PUEBI). Thus, the students are not burdened by the amount of material that must be memorized. The students read each PUEBI concept and can even understand the material through their own questions and answers. The lecturer who teaches the course will check student answers, and analyze and describe if there are wrong answers. Thus, the material and understanding of the students have conformity with PUEBI and KBBI which become standardization in understanding of manuscript editing.

\section{RESEARCH METHODS}

Penyuntingan I course will be carried out using the language card playing method. The students will be formed into the small groups consisting of 6-10 people, then they make 154 language cards which are the application of 154 materials in Law no. 50 of 2015. After that, each group will choose a playing method, such as playing cards, uno card game, monopoly game, or snakes and ladders. When it is their turn to play, they will choose one card and answer the questions on that card. The other play participants will judge the student's answer. Meanwhile, the teaching lecturer will control and supervise the student answers. When there is a wrong answer, the lecturer will explain the correct answer and explain the material related to the question.

To measure the understanding and abilities of these students, during the the mid-semester test (UTS) and the end-semester test (UAS) questions will be given in accordance with the questions listed on the language card and also questions related to the presentation of PUEBI described in class. Thus, there is a synchronization between the material and the students' abilities so that the editing ability of Indonesian Literature Department students can be measured according to the expected standardization.

To evaluate the success of implementing the revised RPS, there are three things that can be used as the indicators of success which are:

\subsection{Learning Outcomes}

The method of playing language cards is said to be successfully applied to the Penyuntingan I course if all learning outcomes can be fulfilled. So far, the Penyuntingan I course has been implemented using the TCL and SCL methods. This method cannot fulfill all the learning outcomes of the course. It is because the students only learn about editing concepts and theories without applying Bahasa rules one by one to the text to be edited. This is due to the large amount of material that will be applied for editing and it make the students to be bored and saturated with editing.

Through the language card playing method, it is hoped that the students can understand all the rules of Bahasa at PUEBI and apply them to the script to be edited.

\subsection{Distribution of Final Score}

This learning method is said to be successful if there are no more students who get $\mathrm{C}, \mathrm{D}$, and $\mathrm{E}$ scores in the Penyuntingan I course learning. It is known from the previous semester the distribution of the student scores was quite good. Although there are no students who get $\mathrm{C}+, \mathrm{C}$, and $\mathrm{D}$ scores, the percentage of the students who get $\mathrm{E}$ scores is still $5 \%$. In the acquisition of previous grades, the highest percentage was found in the acquisition of B values. By applying this method of playing the language cards, it is expected that the highest score of students will be A and the lowest score of students is $\mathrm{B}+$ or A-. The students must understand the rules of the Bahasa according to the Law no. 50 of 2015.

\subsection{The Student Response to the Development of Learning Methods}

It is hoped that project work in learning Penyuntingan $I$ will get a positive response from the students. The students' soft skills will be developed in making language cards in groups, as well as gaining new experiences in learning script editing. By understanding the rules on the cards, they will have knowledge in editing manuscripts.

\section{DISCUSSION}

The method of playing language cards has been applied to the 2019/2020 Even Semester Penyuntingan $I$ course. The application of the language card playing method is carried out for four meetings which is at the 3rd meeting, 4th meeting, 5th meeting, and 6th meeting.

At the 3rd meeting, the students were divided into six small groups and they discussed their respective responsibilities in making questions and making language cards to be played. At the 4 th meeting, the students made 154 language cards themselves consisting of 154 questions. At this meeting, the lecturer checks the questions listed whether they are in accordance with the rules in PUEBI or not. The lecturer guides so that all questions can be answered by other students who will play the card. At the 5th meeting, the students brought the prepared language cards and played card games in the classroom. This game is carried out to get one of the winners. Game winners are given prizes in the form of free lunch or snacks from the losing members' donations.

The card games were also carried out at the 6th meeting so that the students could understand one by one the PUEBI concept applied to the language cards. At the 7th meeting, an evaluation of the students' 
ability to play the language cards was conducted. With this method, at the 7th meeting, the students take a midterm exam (UTS) based on the PUEBI concept that has been played by using the language card. From the games that were carried out, it appeared that there was a change that the students were able to understand the PUEBI concept better than the lecture method or case study through small research in the field.

With the application of the language card playing method in the Penyuntingan I class, the RPS that was used last semester underwent a change. The RPS for Penyuntingan I course in Even Semester 2019/2020 has been revised based on the expected course achievements. The revisions were made for learning materials and methods. The language card playing method was applied to the pre-the midsemester exam meeting and the word editing method was added to the post- the mid-semester exam meeting. Both methods are implemented to support the students' ability to understand Bahasa rules.

Based on the revisions made, the assessment carried out on the student abilities is also revised as follows.

\begin{tabular}{|l|l|l|l|}
\hline No. & $\begin{array}{l}\text { Assessment } \\
\text { Criteria }\end{array}$ & $\begin{array}{l}\text { First RPS } \\
\text { Assessment }\end{array}$ & $\begin{array}{l}\text { Revision } \\
\text { RPS } \\
\text { Assessment }\end{array}$ \\
\hline 1 & Assignment & $20 \%$ & $30 \%$ \\
\hline 2 & The mid test & $35 \%$ & $30 \%$ \\
\hline 3 & The end test & $45 \%$ & $40 \%$ \\
\hline Total & & $100 \%$ & $100 \%$ \\
\hline
\end{tabular}

The revision made to the RPS of Penyuntingan I course for the Even Semester of the 2019/2020 Academic Year is expected to achieve the learning objectives of the course which is (1) the students are able to understand Bahasa principles, (2) the students are able to edit Bahasa text based on Bahasa rules, and (3) the students are able to appreciate the editing profession.

The method of playing language cards is carried out with the aim that the students can understand 154 concepts regarding the Pedoman Umum Ejaan Bahasa Indonesia (PUEBI). Thus, the students are not burdened with the amount of material that must be memorized. The RPS implementation is described into (1) language card making techniques, (2) group members making language cards; (3) language card model, and (4) documentation of the language card game.

\subsection{Language \\ Card Techniques \\ Making}

The application of the 154 concepts regarding PUEBI is carried out in the following ways.

3.1.1. Students are divided into six groups.

3.1.2. Each group consists of 10 people.

3.1.3. Each group understands 154 concepts in PUEBI by copying the rules into a language card and making questions related to these rules.
3.1.4. Each group copies the rules and questions into the form of language cards. The agreed language card design is as follows.

\begin{tabular}{|c|}
\hline Category \\
\hline Theory \\
\hline Question \\
\hline \\
\hline
\end{tabular}

3.1.5. Each group prepares a method of playing language cards.

\subsection{Members of the Language Card Making Group}

Based on these provisions, the students of the Penyuntingan I course have been divided into six groups. The following is a list of the names of the members of each group.

\begin{tabular}{|c|c|c|c|}
\hline No. & $\begin{array}{l}\text { Group } \\
\text { Name }\end{array}$ & Number of Members & Information \\
\hline 1 & Group I & 14 members & $\begin{array}{l}\text { The number } \\
\text { of members } \\
\text { in group I is } \\
\text { more than } \\
10 \text { members } \\
\text { because } \\
\text { some of the } \\
\text { members are } \\
\text { the students } \\
\text { who did not } \\
\text { come to the } \\
\text { meeting } \\
\text { when the } \\
\text { group } \\
\text { division } \\
\text { took place. }\end{array}$ \\
\hline 2 & $\begin{array}{l}\text { Group } \\
\text { II }\end{array}$ & 10 members & \\
\hline 3 & $\begin{array}{l}\text { Group } \\
\text { III }\end{array}$ & 10 members & \\
\hline 4 & $\begin{array}{l}\text { Group } \\
\text { IV }\end{array}$ & 10 members & \\
\hline 5 & $\begin{array}{l}\text { Group } \\
\text { V }\end{array}$ & 10 members & \\
\hline 6 & $\begin{array}{l}\text { Group } \\
\text { VI }\end{array}$ & 10 embers & \\
\hline
\end{tabular}

\subsection{Language Card Model}

Each group prepares six types of language cards. The following an example of the language card. 


\section{THE USE OF LETTERS}

\subsubsection{Abbreviations and Acronyms}

6. Acronyms are not personal names that are a combination of initial letters and syllables or combined syllables written in lowercase letters. For example:

iptek $i$ lmu pengetahuan dan teknologi pemilu pemilihan $u$ mum

puskesmas pusat kesehatan masyarakat

rapim rapat pimpinan

rudal peluru kendali

tilang buk $t i$ pelanggaran

Look at the following data:

Unand

Suramadu

Is the abbreviation or acronym written above correct and what does it stand for?

\section{Language Cards of Group I}

Based on the card, the students played a language card game in the Penyuntingan I course and the game was successfully carried out. The students create the language cards and playing the cards according to the group agreement. The following it shows the language card and the portrait of the language card game.

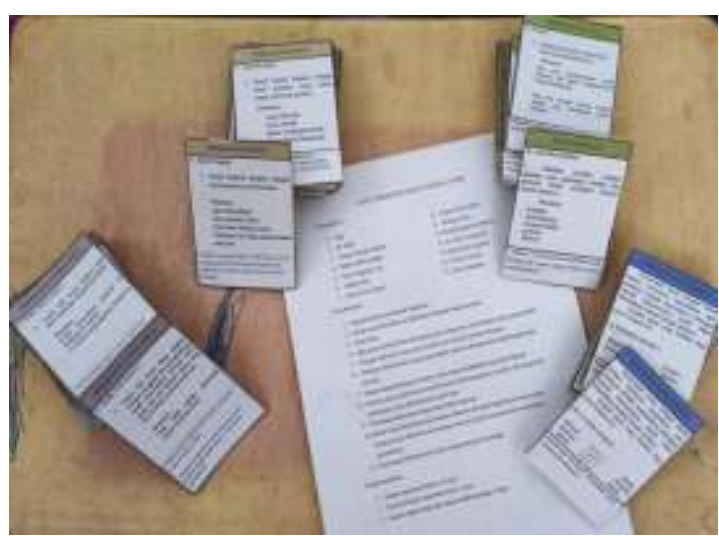

Figure 1.Date of Birth Lucky Card Game(Group I)

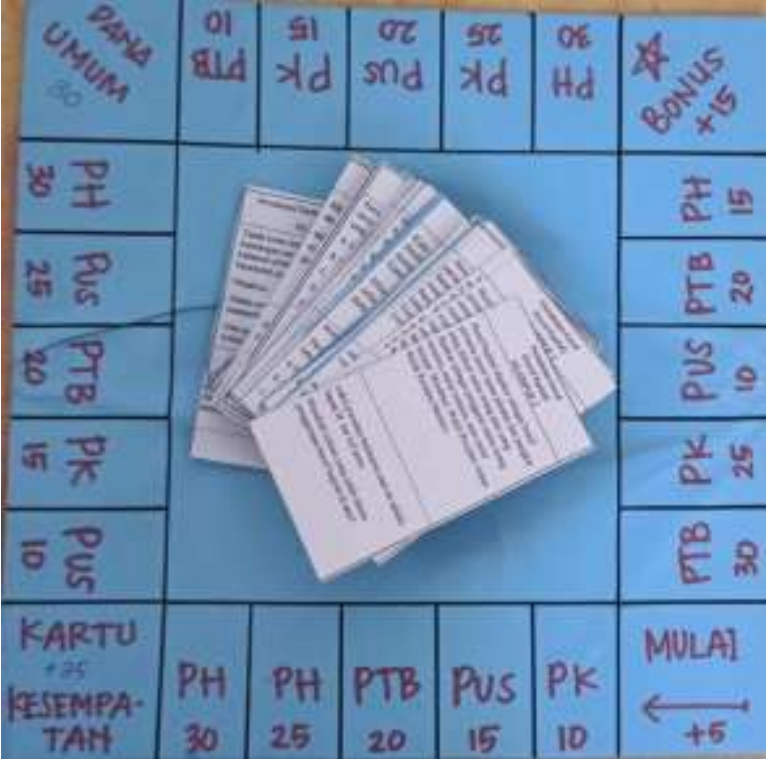

Figure 2.The Kuy Game Card (Group II)

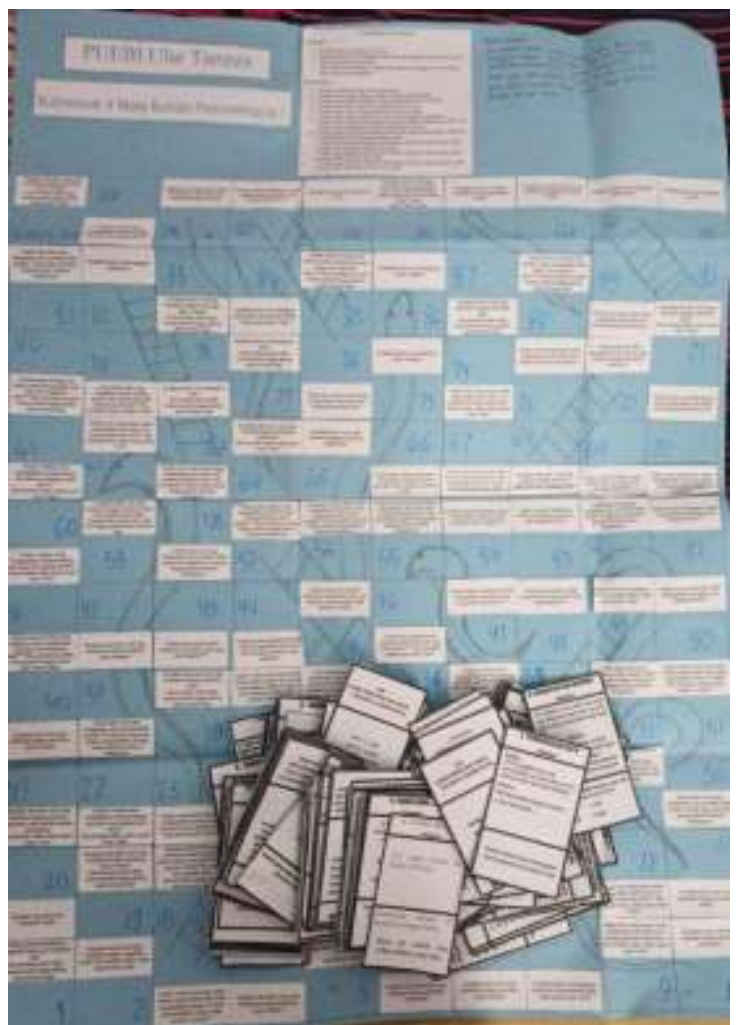

Figure 4. PUEBI Snake and Ladder Card Game (Group IV)

The using the language card, a photo of the implementation of the language card game in Penyuntingan I course as follows: 


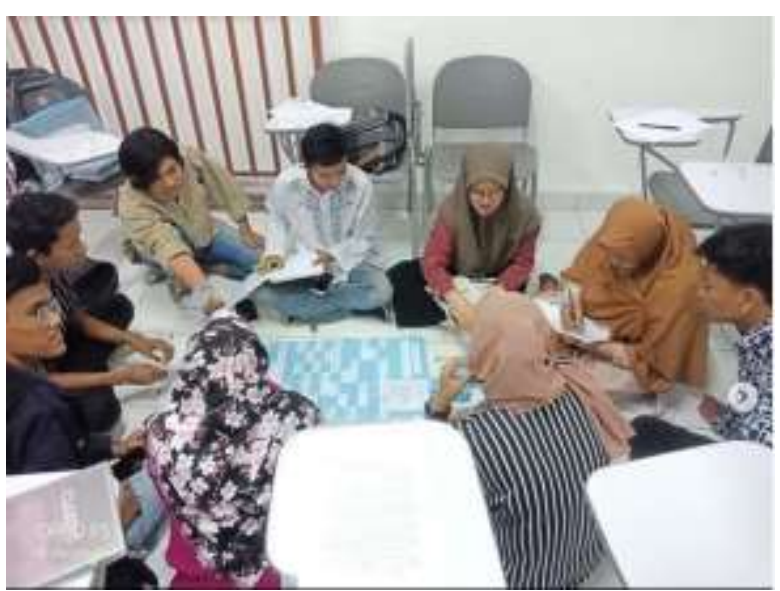

Figure 7. The students of Penyuntingan I are playing cards using the snake and ladder language

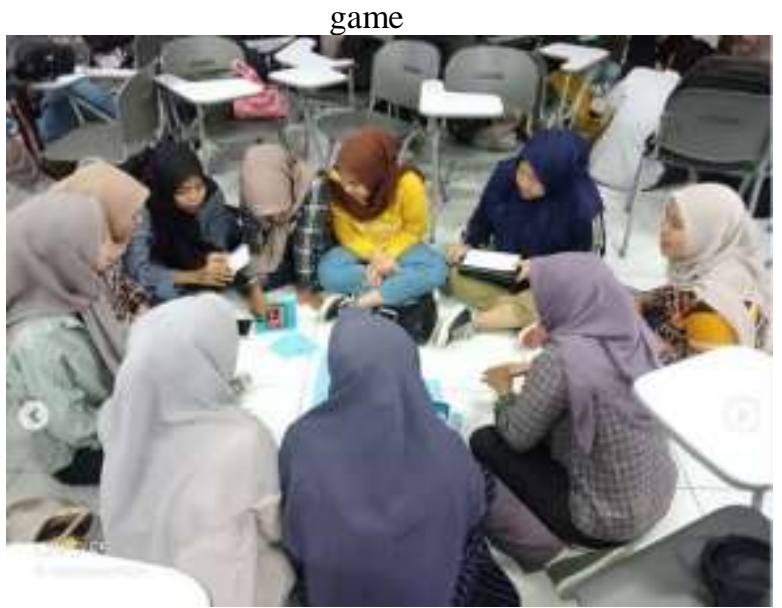

Figure 8. The students of Penyuntingan I are playing the language cards

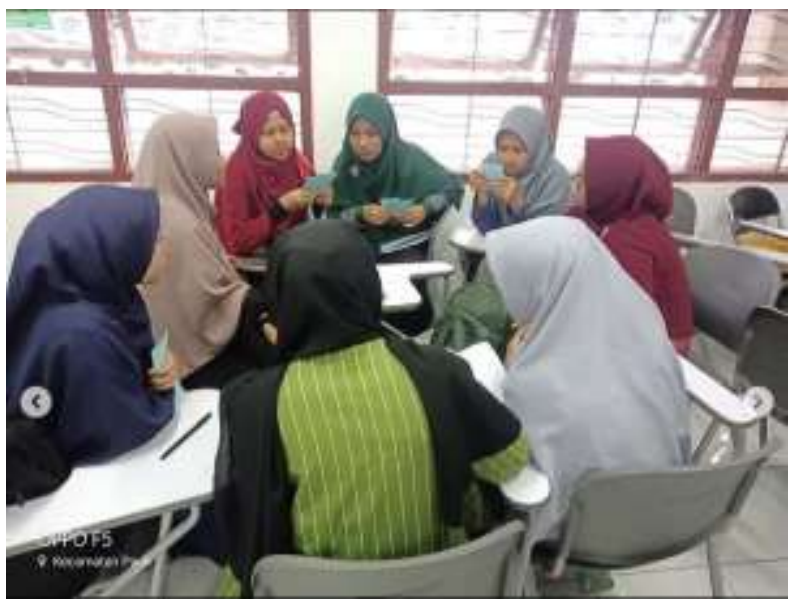

Figure 8. The students of Penyuntingan I are playing the language cards

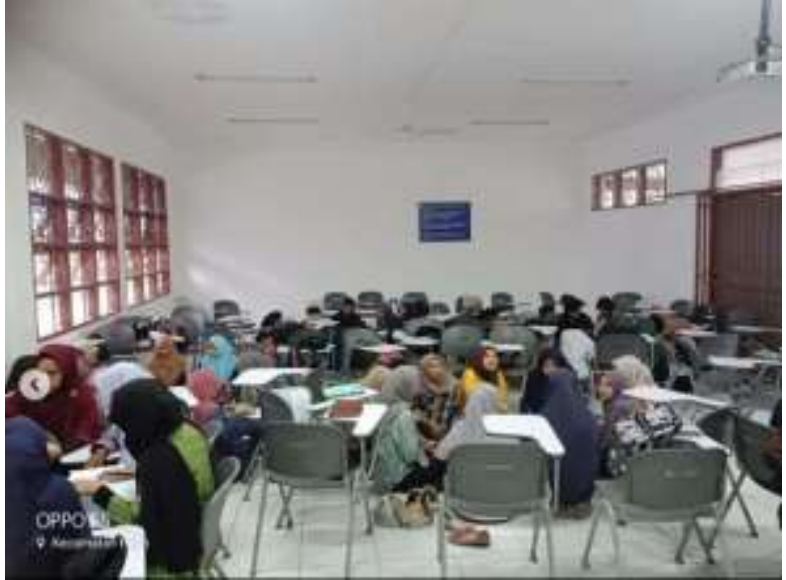

Figure 9. The students of Penyuntingan I are playing the language cards

Based on the implementation of the language card playing method in Penyuntingan I course, there was an increase in the student's ability to understand the rules contained in the Pedoman Umum Ejaan Bahasa Indonesia (PUEBI). At the beginning of the lecture, they were unable to distinguish between letter writing, word usage, punctuation, and absorption of absorption elements correctly. They determine the rules based on the memory of Bahasa lessons in Senior High School (SMA).

During the implementation of the Penyuntingan I course, especially in using the language card playing method, they realized that every writing in Bahasa has rules. In fact, every letter writing in Bahasa has rules or reasons why to use capital letters or not to use capital letters. This can be seen from the indicators of the scores received from the results of the Bahasa proficiency test before the implementation of playing language cards and the the mid-test scores of the Editing course. In addition, other indicators are also used in measuring the ability of the students to understand the rules listed in PUEBI, namely making posts on Instagram with words that are in accordance with the rules of the Bahasa.

The improvement in the student's ability of the

Penyuntingan I course can be seen as follows.

\section{The Results of the Responding to the Rules Test Assessment on the page ukbi.info}

Before starting the language card game, the Penyuntingan I course students' abilities related to the Pedoman Umum Ejaan Bahasa Indonesia (PUEBI) were tested on the ukbi.info page. The ukbi.info page is a Bahasa test page that has been created by Ria Febrina and Sri Wahyuni through research by novice lecturers in 2019. This page can be used to test someone's Bahasa skills. This page is used to test the students' ability in Penyuntingan I before using the language card playing method. The use of this page aims to measure the students' abilities before and after using the language card playing method. It is a sample 
of the student test results from Penyuntingan I through the Bahasa test at ukbi.info.

\begin{tabular}{|c|c|c|c|c|c|c|c|}
\hline \multirow[t]{2}{*}{ No } & \multirow[t]{2}{*}{$\mathrm{xat}$} & \multirow{2}{*}{ 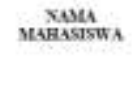 } & & & & & \\
\hline & & & BENAR & SALAR & TERAAW & AtLAS & SE.E: \\
\hline 2 & 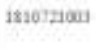 & $\begin{array}{l}\text { Yogitzo } \\
\text { SNTVTRA }\end{array}$ & 10 & 1) & 1s & os $32 \mathrm{WI}$ & timus \\
\hline
\end{tabular}

The average predicate of the Penyuntingan I course of the student's ability before taking the test was a degree. Semenjana ranks are intended for junior high school level students because they have sufficient proficiency in communicating in Bahasa, but they have experienced difficulties in communicating for complex professional and social needs. With this predicate, of course there is concern about the ability of this student as an editor or an Bahasa expert. Thus, the creation of the language card playing method is considered important to improve the students' abilities.

\section{The mid-semester test score in Penyuntingan course}

After following step by step in the language card game, there was a significant increase in the number of students taking Bahasa course. This can be seen in the ability of one of the students who were sampled in this study which is Yori Leo Saputra. Through the ukbi.info test, the predicate obtained by Yori Leo Saputra is semenjana or equivalent to the Bahasa skills possessed by junior high school students. From the results of the mid-semester test assessment, it can be seen that Yori Leo Saputra listens to every theory listed in PUEBI so that the mid-semester test score obtained is in accordance with the achievements of this course which is 82 (numeric value) or A (letter grade). It shows that the language card playing method is effective in helping the students carefully understand the rules of the Bahasa listed in the Pedoman Umum Ejaan Bahasa Indonesia (PUEBI).

\section{Making Posts on Instagram Editorial}

At the meeting after the mid-semester test, the students from the Penyuntingan I course were asked to post standard and non-standard words on Instagram suntingkata. Instagram suntingkata is a social media prepared in this Penyuntingan I course to assist the students in promoting the importance of editing in understanding Bahasa. The student sampled in this course is Yori Leo Saputra, also made a post.

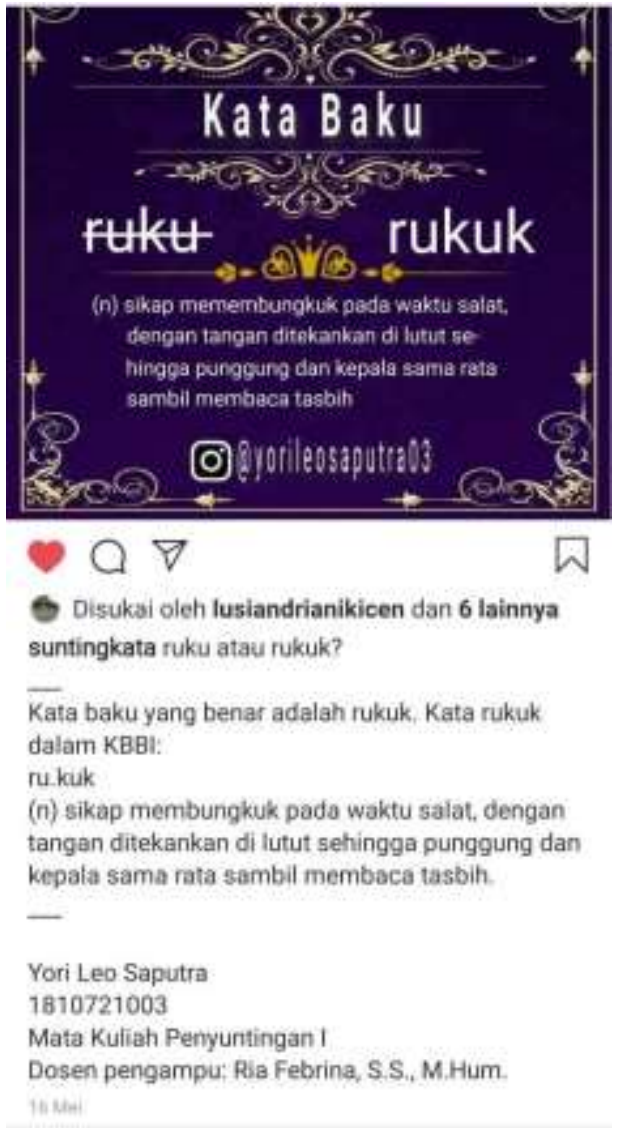

Figure 12. Yori Leo Saputra's post on Instagram suntingkata

With these three indicators, it can be concluded that the language card playing method is effectively implemented as a learning method for Penyuntingan I course. Through this method, the students can understand 154 Bahasa rules in the Pedoman Umum Ejaan Bahasa Indonesia (PUEBI) in a fun way.

\section{CONCLUSION}

The Penyuntingan I course (INA459-Sasindo) is a cluster elective course in semester IV (four) in the Indonesian Literature Department, Andalas University. In this course, the basic theory of editing is discussed from the nature, categories, patterns, conditions, and stages of editing. The material in the practical field includes how to edit various texts for various purposes, as well as language editing practices, both spelling, words, diction, phrases, sentences, paragraphs, and discourse.

Even though it has been studied by the students of the Indonesian Literature Department of Andalas University, based on the results of the Bahasa test carried out, the Bahasa proficiency students of the Indonesian Literature Department, FIB Unand, are on average in the madya rank with a score of 482-577 and a semenjana rank with a score of 405-481. However, the method of playing language cards is effectively implemented as a learning method for Penyuntingan I course. Through this method, the 
students can understand 154 Bahasa rules in the Pedoman Umum Ejaan Bahasa Indonesia (PUEBI) in a fun way.

\section{ACKNOWLEDGMENT}

This article is the output of the Andalas University of Pengembangan dan Penjaminan Mutu Pendidikan (PPMP) in 2020. We would like to thank the Andalas University of Lembaga Pengembangan Pendidikan dan Penjaminan Mutu (LP3M)

\section{REFERENCES}

[1] Abidin, Yunus. Penelitian Pendidikan Dalam Gamintan Pendidikan Dasardan Paud. Bandung: Rizqi Press. (2011).

[2] Ardy, W. Novan dan Barnawi. Format PAUD. Jogjakarta: Ar-Ruzz Media.(2012).

[3] Badan Pengembangan dan Pembinaan Bahasa Republik Indonesia. Kamus Besar Bahasa Indonesia. Jakarta: Badan Pengembangan dan Pembinaan Bahasa Republik Indonesia. (2016).

[4] Badan Pengembangan dan Pembinaan Bahasa Republik Indonesia. "Pedoman Umum Ejaan Bahasa Indonesia (PUEBI)”. Jakarta: Badan Pengembangan dan Pembinaan Bahasa Republik Indonesia. (2015).

[5] Febrina, Ria dan Sri Wahyuni. "Penggunaan Fitur Uji Bahasa Indonesia pada Laman Ejaan.id/cat untuk Mengukur Kemampuan Bahasa Indonesia Mahasiswa FIB Unand. Prosiding Seminar Nasional Jurusan Sastra Indonesia FIB Unand. Padang: Jurusan Sastra Indonesia, Fakultas Ilmu Budaya, Universitas Andalas. (2018).

[6] Menteri Pendidikan dan Kebudayaan Republik Indonesia. "Peraturan Nomor 70 Tahun 2016 tentang Standar Kemahiran Berbahasa Indonesia". Bahan Makalah pada Sosialisasi Uji Kemahiran Bahasa Indonesia Balai Bahasa Sumatera Barat. Padang: Balai Bahasa Sumatera Barat. (2016).

[7] Mutiah, Diana. Psikologi Bermain Anak Usia Dini. Jakarta: Kencana. (2010).

[8] Permendikbud. (2014). Peraturan Menteri Pendidikan dan Kebudayaan RepublikIndonesia Nomor 57 Tahun 2014 Tentang Kurikulum 2013 SekolahDasar/Madrasah Ibtidaiyah.

[9] Widiatuti, Udiati. "Uji Kemahiran Berbahasa Indonesia sebagai Sarana Evaluasi dalam Perencanaan Bahasa di Indonesia". Jurnal Linguistik Indonesia, No. 1. (2006).

[10] Utami. "Pengaruh Penggunaan Media Kartu Huruf terhadap Kemampuan Membaca Permulaan Siswa Kelas 1 SD Negeri 1 Rajabasa Raya Bandar Lampung”. Lampung: Universitas Lampung. (2017).
[11] Yusup, Ukit, dan Dewi. "Penerapan Metode Bermain Kartu pada Pembelajaran Biologi Konsep Echinodermata untuk Meningkatkan Hasil Belajar Peserta Didik”. Bogor: Universitas Pakuan. (2018). 